Зорица Младеновић

Универзитет у Београду

Филолошки факултет

Катедра за општу књижевност и теорију

књижевности

zorica@zimco.com

Ана Радовић Фират

Универзитет у Крагујевцу

Факултет техничких наука Чачак

Катедра за техничко педагошке науке

ana.radovic-firat@ftn.kg.ac.rs
УДК 821.111-1.09

https://doi.org/10.18485/slavistika.2021.25.1.17

Оригинални научни рад примљено 27.03.2021.

прихваћено за штампу 17.06.2021.

\title{
ЗВЕЗДА ДАНИЦА КАО ОДРЕДИШТЕ КУЛТУРНОГ ИДЕНТИТЕТА У ПОЕЗИЈИ РИЧАРДА БЕРЕНГАРТЕНА
}

Овај рад има за циљ да кроз мотив звезде Данице, присутне у свим географским и културним поднебљима, покаже блискост Ричарда Беренгартена са словенском традицијом која је у првом реду песников избор, али и плод фасцинације и посвећености. Непосредност у начину на који је звезда Даница описана и лакоћа интертекстуалног усмерења ка савременој култури у овом случају превазилази песничку инспирацију и јавља се као елемент дескрипције који одговара низу доследности у ауторовом тумачењу словенске традиције, што ће овде бити предмет изучавања. Ради илустрације Беренгартеновог виђења мотива звезде Данице и препознавања њеног значаја у српској традицији, у раду ће се указати на песникову везу са српским песницима и њихову интерпретацију овог мотива као и на значај мотива звезде Данице у народној поезији.

Кључне речи: Ричард Беренгартен, словенско наслеђе, традиција, звезда Даница.

This paper aims to analyse the motif of Venus (Danica the star), present in all geographical and cultural regions, in relation to the poetics of Richard Berengarten. The motif of the star Danica in Berengarten's poetry reveals the author's intimacy with Slavic tradition, not only as the poet's choice, but also as the consequence of fascination and commitment. The ease of intertextual orientation towards contemporary culture in Berengarten's poetics transcends poetic inspiration and appears as an element of description corresponding to a series of consistencies in the author's perception of Slavic tradition. This paper analyses Berengarten's view on the motif of the Venus (Danica) and explores the author's relationship with some Serbian poets, focusing on the significance of this motif in Serbian tradition.

Keywords: Richard Berengarten, Slavic heritage, Slavic tradition, Venus (Danica).

Ричард Беренгартен је британски песник, рођен 1943. године у Лондону. Први пут је дошао у Југославију 1982. године да би присуствовао Београдском међународном сусрету писаца. Исте године издао је у Кембриџу збирку Црна светлост (Black Light) посвећену успомени на грчког песника Јоргоса Сефериса, чије целокупно дело прожима тема односа таме у светлости, и британског историчара Питера Менсфилда (Peter Mansfield), чије су књиге и новински чланци, будући да је шездесетих година био дописник Сандеј тајмса, 
заинтересовале Беренгартена за Блиски исток. У наредним годинама, доласци су постали чешћи а од 1987. до 1990. године, Беренгартен је живео у Београду обилазећи неуморно југословенски регион. Повремени доласци су настављени до данас. Његов превод изабраних песама Тина Ујевића изашао је 2013. године у Британији (Ujević 2013). Са културним наслеђем Балкана, Беренгартен се упознавао слојевито, почев од менталитета појединаца и етничких група, до заједничких карактеристика народа и њиховог предања. Инспирисан словенским наслеђем, написао је у периоду од 2006. до 2008. године „Балканску трилогију”, конципирану као поетско-историјски запис о обичајима и људима југословенске регије. Прва збирка $У$ време суше кроз песме додола усмерена је ка предању и миту. Друга збирка трилогије Плави лептир посвећена је људима, холокаусту, смрти и животу. Под балканским светлом (Under Balkan Light), ${ }^{1}$ трећа збирка песама, представља врхунац песникове перцепције народа на југословенском простору. Присуство снажне емпатије у песмама посвећеним страдалим крагујевачким ђацима, појавиће се и у овој збирци. Она, осим тога, обилује именима, посветама, цитатима и интертекстом како према савременицима тако и према специфичним, од стране песника усвојеним, словенским обичајима. С обзиром да аутор потиче из сасвим другачијег географског и културног поднебља, запажа се како у поступку тако и код одабира мотива специфичан приступ у тумачењу словенске традиције и културне баштине.

Најсложенију симболичку, наративну и композициону улогу код Беренгартена има мотив звезде. Плурално виђење звезде које имамо у његовој поезији одговара њеној представи у митологији и предању Јужних Словена. Колико је она блиска онтолошкој пројекцији космоса Старих Словена, видимо у податку да се у словенској митологији од небеских тела само звезде (и небо) везују за представу космоса док Сунце и Месец имају божанске атрибуте. ${ }^{2}$ Звезде су традиционално везане за судбине људи, могу да утичу на њих и да их мењају. Посебан значај придаван је најсјајнијој звезди, која се није узимала као једна звезда, већ у зависности од тога да ли се појављује ноћу или дању, на северу или истоку, била је Јутарња или Вечерња звезда, Зорњача, Даница или Северњача.

Супротно традицији, у песми „До виђења Данице“ аутор даје сложену слику југословенског микрокосмоса у коме судбина мења Даницу. Иако је она у овој песми превасходно представљена као жена, атрибути звезде чине важан сегмент у композицији песме. У песми је груписан скуп симбола који прате звезду Даницу и који се са њом доводе у везу. Лирски субјекат се њој, међутим,

${ }^{1}$ Две збирке песама које чине Балканску трилогију објављене су у преводу Вере В. Радојевић. У време суше објављена је 2004. године; Плави лептир 2007. године. Збрика Под Балканским светлом (Under Balkan Light), у којој се налази песма „До виђења Данице“, није преведена на српски језик. Песма је, међутим, двојезично објављена у оригиналном писму и са преводом Вере В. Радојевић у издању Српске књижевне задруге, 2011. године. У овом раду користе се цитати издања Српске књижевне задруге.

2 „Задатак нашег речника јесте најсажетији опис модела света грађеног на митолошким основама. (...) У избору одредница пошло се од структуре традиционалног модела света који се може разложити на неколико саставних елемената или категорјалних целина. (...) Одреднице које описују простор могу се разврстати у следеће групе: 1 . Космос - дрво света, исток-запад, звезде, Воласиње - Влашћи, земља, небо" (Толстој, Раденковић 2001: 10). 
обраћа искључиво као жени. Истовремено је као слика жене у времену послератне Југославије, метафора за земљу која пропада. Иако се на паралелу са Југославијом ни на једном месту не указује отворено, Беренгартен је у овој песми створио снажну слику Југославије и омогућио да лепота народног предања, обичаја, навика и живота траје и након формалног краја Југославије коју је он познавао. Мноштво Даница са истим животима и различитим судбинама се у овој песми стапа у једну бесмртну и безвремену жену, представљену као прамајку, сестру, љубавницу, земљу и звезду. Она је стога бљесак вечности, тренутак када читалац постаје свестан постојања нераскидивог поретка који почиње и завршава се на небу. Слику Даничиног живота песник ставља у небески рам како би потврдио њен однос са звездом. У овом сегменту најуочљивије је присуство звезде. Песма почиње и завршава се на небу. Симболично, на почетку од звезде постаје жена да би се на крају жена претворила у звезду. Распрострањено веровање да свако има своју звезду која се пали у часу рођења и гаси у часу смрти (уп: Кулишић и др. 1970: 73, 113; Толстој, Раденковић 2001: 191-192), измењено је наглашеном вечношћу звезде Данице. Звезда која симболизује почетак живота, јавља се и у другим песмама код Беренгартена, на пример у „Отац детету “(Father to small child), где се као траг људског живота на небу стварају отисичи звезда (imprints of star; Berengarten 2008: 57). Као симбол живота након смрти она је звезда која сија на грудима стрељаних Јевреја у Јасеновцу у песми „Спомен плоча за принудне раднике“ (Memorial tablet for a slave labourer; Исто 2008: 45).

У наведеним песмама, Беренгартен није случајно од свих небеских тела одабрао звезду. Њена симболика присутна је у свакодневном животу и чини, поготово у случају звезде Данице, опште место. Песник је препознао њен значај, односно колико је важна као посредник међу небеским телима али и између људи и небеских тела. Стога је његово виђење звезде Данице идентично представи у народној поезији. У песми „Женидба сјајнога месеца“ звезда Даница, месечева сестра, женику бира младу и сватове.

Фалила се звијезда даница:

„Оженићу сјајнога мјесеца,

Испросићу муњу од облака,

Окумићу Бога јединога” (Караџић 1975: 176).

Њена повезаност са људима, иако се не дефинише у песми, препознаје се у завршним стиховима, где невеста дарује сватове. Осим што су дарови намењени људима, тј. они ће од њих имати користи (и штете), уједно се тумаче природне појаве и именују њихови божански узрочници:

Стаде муња даре дијелити:

Даде Богу небесне висине,

Светом Петру Петровске врућине,

А Јовану леда и снијега,

А Николи на води слободу,

А Илији муње и стријеле (Исто). 
Тројство небеског, еротског и колективног у песми „До виђења Данице“ представљено је звездом која је у предању једног државотворног народа одувек имала улогу и оностраног и световног. Док су остала небеска тела чврсто везана за своје појавне облике, звезда Даница садржи спектар категорија и значења. Премда су сва небеска тела у словенској митологији персонификована, само се код звезде Данице спекулише о земаљском пореклу. Словенско предање бележи да је звезда Даница настала пошто се на небо узнела прерано умрла девојка (уп.: Кулишић и др. 1970: 73, 113; Толстој, Раденковић 2001: 192), што је људима чини још ближом и приснијом. У поезији је присутна као невеста и сестра, најчешће у односу на друга небеска тела, пре свега Сунце и Месец. Чињеница да је њено име Даница (јер се и по дану може видети на небу), исто код свих словенских народа, указује на значајно место које је имала у њиховом животу. Звезда Даница је истовремено блиска и далека, наклоњена и сунчевом и месечевом принципу, њена лепота је заводљива и заштитничка. Народна поезија се ослања на предање где се најсјајнијој звезди даје више имена, па се отуда зове још и Преодница - када се на небу појави пре Сунца, и симболично му показује пут. ${ }^{3}$ Пример који следи, доноси дијалог Преоднице и Данице:

Преодница Даници беседи:

„Ој Данице, лена лежавкињо,

Ти прележа од вечер` до света,

Ја обиђо земљу и градове (Караџић 1974: 275).

Беренгартеновна звезда такође обилази 'земљу и градове'. Она се, међутим, на том путу креће ретроактивно, тражећи по прошлости места која се могу наћи само у сећању.

Осим у народним лирским песама, где су небеска тела носиоци сижеа песме, њихово присуство видљиво је у великом броју епских песама где служи као оквир радње и у извесном смислу верификација поетски схваћене истине. Овај поступак показује још једну развојну етапу у процесу сједињења мита и традиције на коју указује Сретен Петровић у књизи Српска митологија: Да би народ, у овом случају Срби, „створили митолошки систем богова као своју персонификовану верзију божанства, таква митологија у националном кључу захтевала је специфичан социјални контекст (...), да се етнички бесадржајна основа конкретизује сопственим историјским ликовима" (Петровић 1999: 9). У народној епској песми „Диоба Јакшића“ која започиње дијалогом Месеца и звезде Данице у свадљивом тону, слика небеских тела представља увод у епски приказ односа браће Јакшић, српских властелина. Небеска тела сведоче о ономе што се догодило, звезда Даница је наиме „дангубила”

Гледајући чуда великога,

Ђе дијеле браћа очевину,

Јакшић Дмитар и Јакшић Богдане (Караџић 1988: 448).

\footnotetext{
${ }^{3}$ Исто.
} 
Како се песма односи на интерпретацију историјских личности, небеска тела се у песми више не спомињу. Спомињање на почетку песме показује њихово присуство у културној традицији. ${ }^{4}$ У формалном смислу, Беренгартенов однос према звезди у „До виђења Данице“ је најсличнији народној песми „Диоба Јакшића“". Испевани стихови имали би и код њега и код народног певача исто значење и без Данице. Са њом, међутим, добијају небеску нит ка свевидећем сведоку непомућеног кредибилитета.

Почетни стихови песме „До виђења Данице“ показују перспективу звезде:

\section{ВОЖДОВАЦ}

Данице, са својим горким црним трешњама и небеским

јоргованима који се раскошно шире по обронцима

(...)

\section{ЗЛАТИБОР}

Данице, жалосних врба и липа,

Данице сова и врабаца

Данице храстова и букава (Беренгартен 2011: 31).

Даница се код Беренгартена симболично спушта са неба и постаје жена. Овај процес одвија се градацијски, тако да стихове њеног појављивања као младе несташне девојчице на улицама Задра, Трогира и Сарајева прате стихови у којима је и даље присутна перспектива звезде изнад Дубровника и Солина:

\section{ЗАДАР, ТРОГИР}

Данице, која се вереш преко опасних стеновитих испупчења испираних пеном;

\section{CAPAJEBO}

Данице, сувише има супротних ветрова који мрсе твоју косу

да би то било добро за твој властити мир,

безбедност и сигурност;

(...)

РАГУЗА

Данице живахних трговачких градова и

збрканих занемарених периферија

${ }^{4}$ Велики број епских песама почиње сликом небеских тела, углавном, да би се успоставио временски оквир где се зора и свитање везују за почетак радње а залазак сунца, појава Вечерњаче и Месеца за окончавање епске приче. Осим горњег примера овај поступак дат је у песми „Чавић Мустај бег и Кара-Ђорђије“: ,, Још зорица не забијелила, / Ни даница помолила лица,/ И од дана ни спомена нема,/ Док покликта са Јавора вила““ (Караџић IV 1986: 408). 


\title{
СОЛИН
}

где остаци амфитеатара,

обрасли бршљаном и ладолежом

надгледају мореузе (Беренгартен 2011: 32, 33).

Постепена метаморфоза звезде у жену најављује Даничино свевидеће и свемогуће биће, каквим ће се у песми показати. Осим што је свеприсутна, она је и неустрашива и несавладива попут звезде у народном предању. У песми „Сунчева сестра и паша тиранин“, девојка сунчева сестрица, мјесечева првобратунчеда, Даничина Богом посестрима без по муке савладава пашу и сватове тако да „не утече ока за свједока / Ни да каже како погибоше“ (Караџић 1975: 177). Изазови које има звезда (жена код Беренгартена) другачијег су метафоричког порекла. Они потичу из стварног живота и усмерени су ка свакодневици, на овом месту са ироничном дистанцом лирског субјекта:

\author{
ПАЛИЛУЛА \\ Данице која два дана, од јутра до вечери, \\ припремаш јела за своју Славу; \\ ДЕДИњЕ

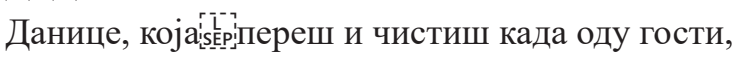 \\ празниш пепељаре \\ пуне просутог вина, бришеш, \\ гланцаш, штиркаш, пеглаш, \\ поново одлажеш своју девојачку спрему у чисти \\ свилени папир (Беренгартен 2011: 37, 38).
}

Географска перспектива Вождовца, одакле се на Београд, главни град свих Југославија, гледа са брда, као што га још нерођена Даница гледа са неба, узета је за почетак песме јер се управо ту, изнад Вождовачког брда појављује Даница, одакле се може видети и ујутру и увече. Песма, која се мора сврстати у фанопеју, овом сликом добија још једну наративну димензију коју ствара, тачније, склапа читалац и која је богатија, што је његова блискост са описаним мотивима јача. Подједнако паундовски алузивна је и песма „Ламент над Београдом“ Милоша Црњанског са сликом Зорњаче изнад Београда, која такође позива читаоца да оживи сопствени низ слика.

Ти, међутим, растеш, уз Зорњачу јасну, са Авалом плавом, у даљини, као брег.

Ти трепериш, и кад овде звезде гасну, и топиш, ко Сунце, и лед суза, и лањски снег (Црњански 1983: 263).

Веза између интерпретације звезде Црњанског и Беренгартена овде се не узима у циљу показивања интертекстуалног односа једне песме према другој, 
већ као још један показатељ Беренгартеновог проницања у културно наслеђе Срба, тј. Словена. На примеру звезде (Данице) уочавамо паралеле између Беренгартена и српских песника, односно, идентичан интерпретативни модел овог мотива. Вечити сјај звезде у релацији са изгубљеном земљом (са отетим Косовом), чест је мотив код Алека Вукадиновића. У песмама „Ласта скривалица“" и „Вејте пахуље најцрњег снега“, дом је мистична и ирационална категорија, дата најчешће у сновиђењу кроз метафору звезде.

На млечној стази, без крова и ушћа

Расла ми роса крај звездане леје.

(...)

Светлости благе, умируће

Најтишег краја благи двори

Тишина - потоња звезда куће

Спрема се врата да затвори (Вукадиновић 2007: 36, 38).

Црњански, Вукадиновић и Беренгартен деле слику отетог, односно изгубљеног дома. Док га Црњански препознаје у најразличитијим местима света, Беренгартен дом проналази и губи у Југославији. Вукадиновићев дом чини се одувек обележен ратом и издајом. Зато космос у његовој поезији чине „скупови црних једначина, мрклина̂, маглина̂“... (Вукадиновић 2007). Као и код Беренгартена и Црњанског, ни име Вукадиновићевог изгубљеног дома се не спомиње у песми. За њега, међутим, „Дечани стоје као звезда на стражи цивилизације и културе“ (Вукадиновић 2012). У разговору са новинарком Новости он ће поновити да су „Дечани најдивнија и најболнија тачка његове животне историје” (Вукадиновић 2019). Беренгартен ће слично рећи о Југославији: „Био сам веома тужан што се Југославија распала, а тема је дошла из тог осећања. И моје остале балканске књиге, посебно У време суше, говоре о распаду Југославије. Она више не постоји, морао сам да одем и отуд наслов ‘До виђења Данице'. Много сам везан за ту земљу и све што се десило тешко сам поднео“ (Б. Ђ. 2012).

Поезија Јове Илића је у смислу односа према звезди, земљи и жени такође блиска Беренгартеновој перцепцији. И његове песме се у великој мери ослањају на фолклор и наслеђе. У сонетима је Србија, на пример, „Даница међу звездама / Најдивнија од свих земаља“" (Илић 2018).

Милорад Павић песму „Симонида“ Милана Ракића и угашене звезде чију светлост још увек видимо, узима као антипод стиховима Огиста Доршена (Auguste Dorchain) и Силија Придома (Sully Prudhomme) који певају о угаслим звездама, поредећи их са зеницама које се гасе (песма „Очи“ Силија Придома), односно са звездама које су тек настале и чија светлост још није дошла до наших очију, док светлост која стиже до нас потиче од угаслих звезда (Доршен у песми „Идеал“). Павић истиче и Готфрида Келера (Gottfried Keller) и његову песму „Видиш ону звезду“ (Siehst du den Stern), где се светлост угашене звезде пореди са неузвраћеном љубављу. Отуда, поред метафоре Симонидиних ископаних очију, Павић у Ракићевој песми, у сјају угашених звезда, види љубав која је ишчезла. „Међутим, ни Келер, ни Придом, ни Доршен, нису имали нигде 
на поприштима својих отаџбина ону оскрнављену цркву са неугаслим бојама једне несрећне фреске, да њиховим стиховима и звездама позајме од своје вечите лепоте, као што Симонида дели своју лепоту са Ракићевом песмом и даје од светлости својих очију, светлост угашеним звездама нашег песника" (Павић 1976: 410-415). У Беренгартеновој „Песми за Анђелку“ стихови „на твом небу нема више места ни за једну звезду“ (No space left in your sky for any more star) (Berengarten 2008: 79), алузија су блиске смрти, односно споменутог веровања о звезди као небеском знаку живота. Песма је посвећена стрељаној ратној заробљеници.

Ниједна Беренгартенова звезда не одлази на небо да би се удала за Сунце или Месец. Даница не одлази ни да би се тамо, на небу, њен сјај угасио. Она одлази да би вечно сијала. Песник је изузетним сензибилитетом за фолклор српског народа, препознао њено трајање. Беренгартен зато са нама дели ону малу цркву о којој Павић говори и у њој фреску младе српске краљице из Ракићеве песме, којој варвари и дан- данас копају очи. Блискост коју је аутор Балканске трилогије остварио са, за њега новом, традицијом учинила је да се порекло колективног мита народа Балкана у његовој поезији означи као део његове подсвести. Он је на Балкану открио народ који живи свој колективни мит, боравећи у Југославији, он је и сам живео тај мит. За разлику од оних који се са тим митом рађају, он је могао да га посматра са дистанце и да формира нова, другачија искуства.

Туђем културном наслеђу се може приступити посредно, енциклопедијски, при чему се полази од интересовања за један културни или традиционални сегмент, што доводи до ширег интересовања за културу, традицију и мит, тако да се изучавањем тих самих категорија опажа њихово присуство у савременом животу, односно стваралаштву. Наш песник, међутим, бира непосредни, егзистенцијални, приступ, где се интересовање за културно наслеђе једног народа јавља из непосредног живота у тој култури, односно доживљаја његове интерпретације у савременом животу. Он није упознао само наше наслеђе већ је доживео његово присуство у савременом свету. Његов приступ словенском наслеђу одвијао се уназад (аналогно кретању планете коју зовемо звездом Даницом).

Стечена блискост учинила је његову поезију својеврсним сведочанством народа Балкана. У раду су показана места где се митско и традиционално спаја са свакодневницом. „Текст тако постаје сведоком контекста, писано дело пак сапутником усмене комуникације” (Сувајџић 2010: 243).

Такође, указано је на одлике Беренгартеновог виђења словенског наслеђа, где његова песничка имагинација чини да древни симболи оживе и отпочну трагање за новим идентитетом, поставши тако метафора песника у потрази за смислом, што истовремено указује на везу са српским песницима чију је филозофску мисао Ричард Беренгартен препознао као сопствену. 


\section{Цитирана литература}

Б. Ђ. „Ричард Беренгартен представио поему посвећену Југославији“. Новости, 03.05.2012. < <ttps://www.novosti.rs/вести/култура.487.html:378184-РичардБеренгартен-представио-поему-посвећену-Југославији> 09.07.2021.

[B. Đ. „Ričard Berengarten predstavio poemu posvećenu Jugoslaviji“. Novosti, 03.05.2012. < <ttps://www.novosti.rs/вести/култура.487.html:378184-РичардБеренгартен-представио-поему-посвећену-Југославији> 09.07.2021]

Вукадиновић, Алек. Дечани су центар целог мог живота, Новости, 24.02.2012. $<$ https://www.novosti.rs> 09.07.2021.

[Vukadinović, Alek. Dečani su centar celog mog života, Novosti, 24.02.2012. <https:// www.novosti.rs $>09.07 .2021]$

Кулишић, Шпиро, Петар Ж. Петровић и др. . Српски митолошки речник. Београд: Нолит, 1970.

[Kulišić, Špiro, Petar Ž. Petrović i dr.. Srpski mitološki rečnik. Beograd: Nolit, 1970]

Павић, Милорад. „Змај, Ракићева Симонида и једна песма Готфрида Келера”. [У:] Милан Стевчић (ур.) Језичко памћење и песнички облик. Нови Сад: Матица Српска, 1976.

[Pavić, Milorad. „Zmaj, Rakićeva ‘Simonida' i jedna pesma Gotfrida Kelera“. U: Milan Stevčić (ur.) Jezičko pamćenje i pesnički oblik. Novi Sad: Matica srpska, 1976]

Петровић, Сретен. Српска митологија I књига. Просвета: Ниш, 1999.

[Petrović, Sreten. Srpska mitologija I knjiga. Prosveta: Niš, 1999]

Сувајџић, Бошко. Певач и традиција. Београд: Завод за уџбенике, 2010.

[Suvajdžić, Boško. Pevač i tradicija. Beograd: Zavod za udžbenike, 2010]

Толстој, Светлана, Љубинко Раденковић. Словенска митологија. Енциклопедијски речник. Београд: Zepter Book World, 2001.

[Tolstoj, Svetlana; Ljubinko Radenković. Slovenska mitologija. Enciklopedijski rečnik. Beograd: Zepter Book World, 2001]

Ujević, Tin. Twelve Poems. Cambridge: Shearsaman Books, 2013.

\section{Извори}

Беренгартен, Ричард. До виђења, Данице - збогом балканска лепотице, превела: Вера В. Радојевић. Београд: Српска књижевна задруга, 2011.

[Berengarten, Ričard. Do viđenja, Danice - zbogom balkanska lepotice, prevela: Vera V. Radojević. Beograd: Srpska književna zadruga, 2011]

Вукадиновић, Алек. Записи о српским светињама. Билећа: Нова зора. СПКД Просвијета, 2012.

[Vukadinović, Alek. Zapisi o srpskim svetinjama. Bileća: Nova zora. SPKD Prosvijeta, 2012] Вукадиновић, Алек. Књига прстенова: Изабране и нове песме. Београд: Задужбина „Десанка Максимовић”, Просвета: 2007.

[Vukadinović, Alek. Knjiga prstenova: izabrane i nove pesme Beograd: Zadužbina „Desanka Maksimović”, Prosveta; Narodna biblioteka Srbije, 2007]

Илић, Јова. Поезија: Антологија књижевнсоти за децу 1. Нови Сад: Издавачки центар Матице српске, 2018.

[Ilić, Jova. Poezija: Antologija književnsoti za decu 1. Novi Sad: Izdavački centar Matice srpske, 2018] 
Караџић Стефановић, Вук. Српске народне пјесме из необјављених рукописа. Сабрана дела, књига II - IV. Приредили: Живомир Младеновић и Владан Недић. Београд: Српска академија наука и уметности, 1974.

[Karadžić, Vuk Stefanović. Srpske narodne pjesme iz neobjavljenih rukopisa. Sabrana dela, knjiga II - IV. Priredili: Živomir Mladenović i Vladan Nedić. Beograd: Srpska akademija nauka i umetnosti, 1974]

Караџић, Вук Стефановић. Српске народне пјесме I. Сабрана дела, књига IV. Приредио В. Недић. Београд: Просвета, 1975.

[Karadžić, Vuk Stefanović. Srpske narodne pjesme I. Sabrana dela, knjiga IV. Priredio V. Nedić. Beograd: Prosveta, 1975]

Караџић, Вук Стефановић. Српске народне пјесме I. Сабрана дела, књига IV. Приредио В. Недић. Београд: Просвета, 1988.

[Karadžić, Vuk Stefanović. Srpske narodne pjesme I. Sabrana dela, knjiga IV. Priredio V. Nedić. Beograd: Prosveta, 1988]

Караџић, Вук Стефановић. Српске народне пјесме, скупио их и на свијет издао Вук Стеф. Караџић. Књига четврта у којој су пјесме јуначке новијих времена о војевању за слободу, у Бечу, у штампарији јерменскога манастира, 1862. Сабрана дела, књига VII. Приредио: Љубомир Зуковић. Београд: Српска академија наука и уметности, 1986.

[Karadžić, Vuk Stefanović. Srpske narodne pjesme, skupio ih i na svijet izdao Vuk Stef. Karadžić. Knjiga četvrta u kojoj su pjesme junačke novijih vremena o vojevanju za slobodu, u Beču, u štampariji jermenskoga manastira, 1862. Sabrana dela, knjiga VII. Priredio: Ljubomir Zuković. Beograd: Srpska akademija nauka i umetnosti, 1986]

Ракић, Милан. Песме. Београд: Чигоја штампа, 2015.

[Rakić, Milan. Pesme. Beograd: Čigoja štampa, 2015]

Црњански, Милош. Песме. Приредила: Светлана Велмар-Јанковић. Београд: Нолит 1983.

[Crnjanski, Miloš. Pesme. Priredila: Svetlana Velmar-Janković. Beograd: Nolit 1983]

Berengarten, Richard. Under Balkan Light. Cambridge: Salt Publishing, 2008.

Keler, Gotfrid. Gedichte in einem Band. Berlin: Insel Verlag, 1998.

Zorica Mladenović

Ana Radović Firat

\section{VENUS (DANICA) AS THE ORIGIN OF CULTURAL IDENTIY IN THE POETRY OF RICHARD BERENGARTEN}

\section{Summary}

The Balkan Trilogy, written by Richard Berengarten, presents a poetico-historical testimony on the mythological heritage, culture, and folk customs related to the ex-Yugoslavia regions. By exploiting the general principles of myth and history, and trivial and poetical existence, Berengarten's poetic discourse embodies the myth and life of the Slavic people in the Balkans.

Given that the author's origin, in geographical and cultural terms, is different from the culture he depicts, it is evident that the author carefully and very specifically approaches the interpretation of Slavic culture. 
Despite the fact that the motif of the Venus (Danica) is present worldwide, in Berengarten's poetry it reveals the author's intimacy with Slavic tradition, not only as the poet's choice, but also as the consequence of fascination and commitment. The ease of intertextual orientation towards contemporary culture in Berengarten's poetics transcends poetic inspiration and appears as an element of description corresponding to a series of consistencies in the author's perception of Slavic tradition. At the hermeneutical level, in Berengarten's text tradition emerges as an archetype. Nevertheless, viewed from the aspect of narration it is intertextually directed towards reality. A number of motifs (rainmaker, butterfly, cherry tree, bees, lilacs, lone oak...) convey their original meaning from Slavic tradition and gradually bring about the Balkan collective myth emerging in Berengarten's poetics as an integral part of his unconscious self.

This paper analyses Berengarten's view on the motif of the Venus (Danica) and explores the author's relationship with some Serbian poets, focusing on the significance of this motif in Serbian tradition.

Keywords: Richard Berengarten, Slavic heritage, Slavic tradition, Venus (Danica). 